\title{
The Overview and Analysis of the State of Rural Tourism in Croatia
}

\author{
Damir Demonja \\ Institute for Development and International Relations, IRMO, Croatia \\ e-mail:ddemonja@irmo.hr
}

\begin{abstract}
In rural areas of Croatia, which make up $91.6 \%$ of its surface, $44.4 \%$ of the population is directly or indirectly related to agriculture. Taking into account the natural and cultural diversity of Croatian regions, a rich resource base of tourist attractions, preserved environment and 352 registered rural households, Croatia has all prerequisites for the development of rural tourism and all special forms of tourism related to the rural area. This is important because market demand particularly emphasizes the presence of rural tourism and its numerous forms. However, the rural area in Croatia is still insufficiently exploited in terms of tourism. Rural tourism in Croatia can become one of the main determinants of development in areas where it has so far been marginalized. Development of the rural tourism offer, which is attractive to investors and uses the unique local potential, will have a significant impact on the gross domestic product growth rate and employment. The paper is focused on presenting and commenting on the state of rural tourism in Croatia. It is based on the results from previously conducted researches and the new ones, and analyzes the state of rural tourism in Croatia in general, its facilities, carrying capacity, grant and incentive programs and, finally, suggests guidelines for the sustainable development of rural tourism in Croatia.
\end{abstract}

Key words: Croatia, rural tourism, overview, analysis, state, guidelines, sustainable development.

\section{Introduction}

Rural area in Croatia is determined by the territorial division according to which small administrative units, municipalities, are considered as rural areas, and cities as the urban ones. Based on such administrative criteria, from 4,437,460 inhabitants in Croatia, 44,4\% $(1,971,005)$ is considered a rural population and 55,6\% $(2,466,455)$ urban (Ministry of Agriculture, Fisheries and Rural Development of the Republic of Croatia [MAFRD RC], 2008.:7).

However, in order to implement rural development policy, as the most internationally recognized and used criterion for distinguishing between rural and urban areas, is used the OECD definition, which is based on population density. At the local 
level, that municipalities and cities in Croatia, an area classified as rural or urban based on the threshold of 150 inhabitants per $\mathrm{km}^{2}$. At the regional level, the counties in Croatia, the OECD defines three groups of areas, depending on the proportion of the population in the region living in the rural local areas:

- predominantly rural regions: over $50 \%$ of the region's population lives in local rural areas,

- $\quad$ significantly rural regions: $15-50 \%$ of the region's population lives in local rural areas, and

- predominantly urban regions: less than $15 \%$ of the region's population lives in local rural areas (MAFRD RC, 2008::7).

By applying the OECD criteria, according to which areas are classified as rural or urban based on the threshold of 150 inhabitants per $\mathrm{km}^{2}$, in the case of rural areas in Croatia, follows:

- $\quad 91,6 \%$ of the total area of the Republic of Croatia classified as rural, and $8,4 \%$ as urban,

- $\quad 88,7 \%$ of the settlements is located in rural areas and $11,3 \%$ in urban areas with $35 \%$ of the population in 14 cities with more than 30,000 inhabitants, and

- $47,6 \%$ of the total population lives in rural areas and $52,4 \%$ of them in urban areas (MAFRD RC 2008.:7).

According to the Strategy for development of Croatian tourism until the year 2010, it was recognized the need to revitalize the tourism potentials of the continental Croatia. Therefore, great attention has brought to the development of rural tourism. Considering the diversity of the natural resource base and characteristics of rural architecture and traditions in Croatia, it is possible to distinguish seven rural areas:

1. Slavonija, Baranja and Srijem,

2. Hrvatsko Zagorje, Prigorje, Međimurje and Podravina,

3. Posavina, Pokuplje, Moslavina,

4. Gorski Kotar and Žumberak,

5. Lika and Kordun,

6. Istria and Hrvatsko primorje, and

7. Dalmatia (Ministry of Tourism of the Republic of Croatia [MT RC], 2003.:13).

In these rural areas, there are conditions for the development of 19 forms of tourism, namely: agritourism or farm tourism, residential, native, sport and recreational, adventure, educational, transit, camping, nautical, rural, cultural, religious, hunting, fishing, wine, gastronomic/culinary, nature-friendly, eco-tourism, and mixed and other forms of rural tourism.

This paper analyzes recent Croatian literature about rural tourism, discusses the concepts, terms and entrepreneurial forms of rural tourism in Croatia, interprets legislative foundations (frames) of Croatian rural tourism, analyzes the state of tourism in rural areas in Croatia and interprets data on the facilities and capacities of rural tourism in Croatia. Also, this paper interprets and evaluates forms/types of grants and programs for the development of rural tourism and, finally, state and explains the guidelines for further development of tourism in rural areas in Croatia. 


\section{Literature review}

In this literature review it will be presented and discussed in short only recent Croatian literature which is dealing with respected paper theme/subject. Rural tourism in Croatian scientific literature was fully studied and elaborated in a book Rural tourism in Croatia with Croatian best practice examples and European experiences (Demonja and Ružić, 2010.). This book deals with terms and definitions of the rural tourism and describes rural tourist destination, forms of rural tourism and marketing, conditions and guidelines for the development prospects of rural tourism in Croatia and, in the end, gives detailed descriptions of good practice examples in European countries and Croatia including more than thirty individual examples, categorized by types of facilities and forms of rural tourism. Despite the focus on Croatia, the book provides an overview and analysis of rural tourism in Europe in the context of sustainable development, as well as the experience of using structural funds and programs of the European Union.

Besides this book, as a quality base to research rural tourism could serve Proceedings from two of three held congresses on rural tourism in Croatia (Katica, 2010.; Katica, 2010.a.). Both Proceedings consists of scientific and professional articles which are handling a large number of different topics related to rural tourism and discussed on the congresses, they contain richness of numerical and graphical data, and worthy information. Some of the articles are showed examples of good practice, as well as those of international cooperation on the development of rural areas with emphasis on rural tourism. The number and variety of treated topics reveals the complexity of the subject area - rural tourism and authors approach how they understood problems, offering guidance, suggestions and solutions (Demonja, 2011.).

There are a certain number of scientific articles dealing solely with the rural tourism theme. One of the most productive Croatian authors is E. Kušen. He wrote the first important article on rural tourism in Croatia (Kušen, 1992.:365-382), as well as he dealt with specific problems and issues of rural tourism, such as definition and terminology of rural tourism (Kušen, 2010.), than he researched some forms of rural tourism as continental nautical tourism (Kušen, 1995.), residential tourism (Kušen, 1995.a.) and tourism on rural farms (Kušen, 1995.b.). The research interests of P. Ružić (Ružić, 2009., 2011.) is rural tourism from the aspects of ethnology and tradition, rural forms of tourism and rural economy studied mostly in Istria County. Finally, articles of R. Baćac dealt with some specific themes of rural tourism, and the important and actual one is the theme of agritourism. One of his article contains evaluation of existing state of agritourism in Croatia and propose further steps for authentic tourism offer in rural areas (Baćac, 2010.a.:29-32), in the previous one the author discusses suggestions of agritourism developing improvement in Croatia (Baćac, 2010.:23-26), and in other examines and analyzes tradition in agritourism (Baćac, 2006.:36-42). 


\section{Methods}

Methods of the researched theme consisted of:

1. collection and analysis of existing relevant literature and documentation, and analysis of current circumstances relating to tourism and rural tourism in Croatia,

2. collecting and analyzing data, information and research of relevant institutions regarding rural tourism in Croatia (Ministry of Tourism of the Republic of Croatia, Ministry of Agriculture of the Republic of Croatia, Croatian Chamber of Economy, Croatian National Tourist Board), and

3. field work and visits of selected numbers of tourist rural family households, situated in Croatian regions in which rural tourism is sufficiently developed.

\section{Results, analysis and discussion}

\subsection{The concept, terms and entrepreneurial forms of rural tourism in Croatia}

The term rural tourism in Croatia is characterized by name diversity, which implies a relatively new concept in scientific research. However, despite the broad area that covers the term of rural tourism, its essence is focusing on rural (local) economy and its related activities in the natural environment.

Linguistic misunderstandings closely related to the development of rural tourism in Croatia stemmed from the fact that the words village and peasant have the same root, but they are form similar but different adjectives rural and rustic. Since in the past 50 years the adjective peasant had mostly derogatory meaning, it was replaced by the word rural. This is exactly what in the professional terms and legal standards causes many unwanted misunderstandings. In meantime appeared another term in the field of rural tourism, close to the tourism on rural farms, purely marketing purposes, as a reaction to inadequate regulations. It is an agritourism which achieved significant economic success in Istria County.

Later, development of rural tourism economies come to be associated with the development of the entire rural tourism in Croatia, and the term rural tourism, when used only in professional frames has not caused confusion. Selection of a foreign word rural in professional and scientific articles is based on the fact that in the Croatian language there is no an appropriate term for the entire non-urban area, which would stress the difference between a populated (rural) area and the entire one outside of the city. At European level, professional terms based on the root of the word rural is affirmed. At the First Croatian Congress on Rural Tourism, held in Hvar in 2007, due to the frequency of semantic misunderstanding and doubts related to the development of rural tourism in Croatia, especially those on rural farms, was adopted conclusions on the terminology of rural tourism (Kušen, 2010.:131-134). This terminology is, since then, more used in the Croatian scientific and professional literature. 
The term rural tourism has many forms (rural, residential, native, sport and recreational, and others), and most important component is farm tourism, which is very often determined by the syntagm tourism on rural farms. The term has a root in the word farmer, which determines the holder of the development of this form of tourism (Cetinski, Kušen and Katica, 1995.:10-11). Rural tourism in Croatia implies and includes many activities, services and additional contents that organize rural population on family farms in order to attract tourists in their area and create additional revenue. Starting from the mentioned and adding him component of sustainable development, which today is fundamental in rural tourism, in rural areas in Croatia can be recognized basic activities of rural tourism, its special forms and different forms of entrepreneurial organization (Regulation on the provision of catering services in rural household [RPCSRH], Official Gazette 5/08 and Act on providing services in tourism [APST], Official Gazette 68/07, Art. 49-53, and amendments Official Gazette 88/10, Art. 3-6.).

Basic activities in rural tourism are catering (food preparation and catering services, preparing and serving drinks and providing accommodation services) and tourism services (provision of services in tourism). Key regulations that regulate business operations in rural tourism in Croatia are the Act on catering activity and the Act on providing services in tourism, and, in the case of a rural household, the Regulation on the provision of catering services in rural household. According to the existing Croatian regulations there are several forms of entrepreneurial organizing in rural tourism: citizen, craft and trade company. Tourist rural households in rural areas in Croatia are entrepreneurial organized as citizens, and they represent an additional activity of the primary agricultural activity. All other facilities that provide catering services on rural areas in Croatia must be registered as crafts or trade companies.

\subsection{Legislative basis of rural tourism in Croatia}

As already mentioned, the development of rural tourism in Croatia is regulated by the applicable laws and regulations. Considering that rural tourism carried out on rural households of particular importance are the following acts regulating tourism and catering activities at rural household:

- Act on providing services in tourism (Official Gazette 68/07 and 88/10), and

- Act on catering activity (Official Gazette 138/06, amendments Official Gazette 80/13),

- as well as relevant regulations:

- Regulation on the provision of catering services in rural household (Official Gazette 5/08, amendments Official Gazette 44/11 and 118/11),

- Regulation on the classification and categorization of facilities that provide services in the rural household (Official Gazette 88/07, 58/08, 45/09),

- Regulation on registers of catering facilities and on registers of providing catering services in the household and rural household (Official Gazette 5/08),

- Regulation on the form, content and manner of keeping the guests book and the list of guests (Official Gazette 5/08), and

- Regulation on keeping the list of tourists and the form and content of the registration form to the tourist board (Official Gazette 113/09). 
The Act on catering activity in Croatian legislation introduces the concept of providing catering services on rural household, as follows in Chapter VI of that Act. Articles 28 to 37 prescribe the conditions under which rural households can provide catering services and the rules are given in Art. 38.

Providing services on rural household determine the provisions of other regulations. The Regulation on the form, content and manner of keeping the guests book and the list of guests determines the method of recording guests in the household. Regulation on keeping the list of tourists and the form and content of the registration form to the tourist board determined the form for registration and reregistration of tourists. On the provision of catering services on rural households apply certain provisions of the Regulation on the classification and categorization of facilities that provide services in the rural household.

Regulation on the provision of catering services in rural household closely regulates the provision of services on rural households. It specifies that "the facility in a rural household is a functional unit of the rural farm where the guests, depending on the type, provide preparing and serving catering service of meals/dishes and drinks, common for the area/territory where the rural household is settled, from agricultural products primarily of its own production, accommodation services and other services in the function of tourist consumption" (RPCSRH, Official Gazette 5/08, Art. 2). Besides the definition of rural households, this Regulation defined the types of rural household facilities: wine shop/tasting room, excursion site, room, apartment and campsite (Art. 5), as well as general and minimum requirements for each of these types of facilities (Art. 7 to 25). Also, this Regulation determined provision of catering services to guests with accommodation services, such as breakfast or half board or full board, and serving drinks (Art. 9 and 10), which have to be prepared from agricultural products from production of household itself (Art. 3). These Regulation in Chapters IV and V sets out minimum requirements that must be met by rural households for the provision of catering services, than the minimum requirements for individual facilities that provide accommodation services (rooms, apartments, campsites), then the minimum conditions that the rural household must meet to provide nutrition and beverage services. Chapter VII of the Regulation prescribes the classification of facilities which provide accommodation services on rural household, rooms, apartments and campsites, as well as conditions that they must meet. Finally, the Regulation set out minimum requirements and methods of categorization and marking facilities which provide catering services on rural household.

The Act on providing services in tourism defines tourism services and states that the tourist services and other services for tourists provided in connection with their travel and stay also provide in the rural farms or family farms.

\subsection{Rural tourism in Croatia}

The development of rural tourism in Croatia intermittently started in the beginning of 1990s, when the Ministry of Tourism of the Republic of Croatia started the initia- 
tives for its development, and the first activities included field surveys, gathering of information, training initiators and creating prerequisites for its development. The dynamics of stronger development of tourism in rural households and Croatian rural tourism in general started in 1998. During this year, 32 tourist rural households were registered in the Republic of Croatia (Mišćin and Mađer, 2008.). Soon afterwards, the "Rural Tourism Council" was established, which later grew into the "Council for the Development of Small and Medium Entrepreneurship in Tourism" with an emphasis on rural tourism (Kušen, 1995.b.:127-133; Kušen, 1997.:48-51). The Istria County, as a regional self-governing unit, first started getting involved in rural tourism and achieved significant results through its measures.

This was the time when the issue of developing overall rural tourism boiled down to developing rural households. The initiatives by "Croatian Farmer", then Association of Peasants, Ministry of Tourism of the Republic of Croatia, Institute for Tourism in Zagreb and, later, of the Member Club "Village" and the Croatian Chamber of Economy, were focused at first on searching for suitable rural households and animating their owners for reconstruction, for the purposes of rendering tourist and catering services, and creating conditions for their development. Today, numerous prerequisites have been met, so individual rural tourist destinations are being formed.

Systematic development of rural tourism in the Republic of Croatia can be divided into two significant periods. The first period started in 1995 and lasted until the end of 1999, when the Croatian Government adopted the National Program for the Development of Small and Medium Entrepreneurship in Tourism, with an emphasis on sustainable development of tourism in rural areas (Cetinski, Katica and Nušinović, 1998.). Following this, several years of pausing activities ensued, during which period individual initiatives occurred while subsidies by the ministry in charge were lacking. The second period, which witnessed visible improvement in developing this kind of tourism, started by the end of 2003, i.e. at the start of 2004, when the new Government of the Republic of Croatia, through its ministries of tourism and agriculture, started taking more significant care of rural areas and economic activities taking place in rural areas.

\subsubsection{State of tourism in rural areas in Croatia}

Current status of tourism in Croatian rural areas can be objectively presented by analyzing very few publicly available data previously conducted research, and new ones, are available mainly from the annual statistical reports conducted by the Croatian Central Bureau of Statistics. The latter data, as well as those who collect government institutions like ministries, are not segmented and generally do not take into account the complexity and diversity of rural tourism. Also, the problem is the fact that the existing data of the research is difficult to get through the official channels for use in scientific and professional purposes. The last available official data regarding state of rural tourism in Croatia were collected on the year 2007, and they are presented and analyzed in this overview. Also, other data used in this article are 
collected through personal contacts with the relevant institutions involved in rural tourism in Croatia.

In March 2007, the Croatian Chamber of Economy, Tourism Department conducted a survey using a sample of 88 registered tourist rural family households, which encompasses about 25\% out of 352 registered households in Croatia in 2007 (Mišćin and Mađer, 2008.). The survey results, which follow below, are considered significant indicators of the state for further development and adjustment of the legislative framework in the rural area, i.e. rural tourism in Croatia.

Tourist rural family households have turned during the past decade into a new tourist product in the rural areas of Croatia, the fast quantitative growth and qualitative development of which we all witness year in and out (Table 1). Number shows that in the year 1998 there were only 32 registered tourist rural family households, a number of them by 2007 grew 11 times, and that year there were a total of 352 .

Table 1

The number of registered tourist rural family households in the period from 1998 to 2007

\begin{tabular}{|c|c|}
\hline Year & The total number of registered tourist rural family households in \\
Croatia
\end{tabular}

Source: Ministry of Tourism of the Republic of Croatia, Zagreb, 2007

However, despite a positive development trend, analyses show it is not equal in all areas of Croatia, and that there are structural and other differences between households. In individual counties, there are a large number of developed households, while in as many Croatian counties as 6 - there is not a single registered household (Table 2). 
Table 2

Number of registered tourist rural family households, number of beds, catering services and wine/brandy tasting facilities/rooms, as per county, in 2007

\begin{tabular}{|c|c|c|c|c|}
\hline County & $\begin{array}{l}\text { Number of } \\
\text { registered } \\
\text { tourist } \\
\text { rural family } \\
\text { households in } \\
\text { Croatia* }\end{array}$ & $\begin{array}{c}\text { Number } \\
\text { of beds in } \\
\text { households }\end{array}$ & $\begin{array}{c}\text { Nutrition } \\
\text { services }\end{array}$ & $\begin{array}{c}\text { Wine/brandy } \\
\text { tasting } \\
\text { facilities/ } \\
\text { rooms }\end{array}$ \\
\hline Bjelovar-Bilogora & 2 & 16 & 2 & 2 \\
\hline Brod-Posavina & 0 & 0 & 0 & 0 \\
\hline Dubrovnik-Neretva & 70 & 23 & 70 & 70 \\
\hline Istria & 64 & 253 & 47 & 35 \\
\hline Karlovac & 0 & 0 & 0 & 0 \\
\hline Koprivnica-Križevci & 6 & 22 & 5 & 3 \\
\hline Krapina-Zagorje & 7 & 20 & 6 & 6 \\
\hline Lika-Senj & 0 & 0 & 0 & 0 \\
\hline Međimurje & 8 & 10 & 8 & 8 \\
\hline Osijek-Baranja & 56 & 192 & 47 & 3 \\
\hline Požega-Slavonija & 0 & 0 & 0 & 0 \\
\hline Primorje-Gorski Kotar & 0 & 0 & 0 & 0 \\
\hline Sisak-Moslavina & 8 & 27 & 7 & 3 \\
\hline Split-Dalmatia & 31 & 12 & 31 & 16 \\
\hline Šibenik-Knin & 21 & 16 & 21 & 21 \\
\hline Varaždin & 6 & 6 & 3 & 5 \\
\hline Virovitica-Podravina & 0 & 0 & 0 & 0 \\
\hline Vukovar-Srijem & 2 & 0 & 2 & 2 \\
\hline Zadar & 41 & 248 & 11 & 10 \\
\hline Zagreb & 30 & 41 & 28 & 23 \\
\hline Total & 352 & 886 & 288 & 207 \\
\hline
\end{tabular}

* pursuant to the data obtained from Economy Departments of the State Administration Office in counties of the Republic of Croatia

Source: Croatian Chamber of Economy, Tourism Department, Zagreb, 2007

According to data from the year 2007, in the Republic of Croatia are 352 registered tourist rural family households with a total of 886 beds. Of the total number of tourist rural family households, 288 of them or 81\% offering nutrition services, while 207 or $59 \%$ have tasting room (wine, brandy and other).

The number of registered tourist rural family households showing their highly uneven spatial distribution in Croatia. Even 6 counties has no registered nor do a single household, and 7 continental counties have registered less than 10 households. The largest number of registered tourist rural family households is in the Dubrovnik-Neretva County, 70 or $20 \%$, followed by Istria County, which has 64 registered rural family households or 18\%. Istria County has a significantly higher number of registered beds in tourist rural family households, 253 or $29 \%$ of total registered beds in tourist rural 
family households in all Croatian counties. Except the Dubrovnik-Neretva and Istria County, the most significant increase in the number of registered rural households in the continental part of Croatia has the Osijek-Baranja County with 56 registered households or 16\%, and 192 beds or 22\%. On the coast, i.e. east and coastal area of the Adriatic should be pointed out Zadar County with 41 tourist rural households or $12 \%$, and 248 beds or 28\%, then the Split-Dalmatia with 31 tourist rural households and the Šibenik-Knin with 21. In the continental part of Croatia, Zagreb stands out with 30 registered tourist rural family households and 41 beds. Other inland counties such as Sisak-Moslavina, Međimurje, Krapina-Zagorje, Koprivnica-Križevci and Varaždin, also recorded a growth a total of registered tourist rural family households, followed by the Bjelovar-Bilogora and Vukovar-Srijem County. Brod-Posavina, Karlovac, Lika-Senj, Požega-Slavonija, Primorje-Gorski Kotar and Virovitica-Podravina County do not have registered tourist rural family households.

According to the recent official and unpublished data from the Ministry of Tourism of the Republic of Croatia, obtained through personal correspondence, the ministry counts 61 rural households. It is just those rural households that provide accommodation service/overnights stay, while for those that provide nutrition services data are not collected. According to the data (Table 3), the highest number of rural households that provide accommodation service/overnights stay are in Osijek-Baranja County, 23, and in Sisak-Moslavina County, 9. Five rural households with accommodation service are in the Istria County, 4 in Koprivnica-Križevci and Vukovar-Srijem, 3 in Zagreb, Šibenik-Knin and Bjelovar-Bilogora County, 2 in Dubrovnik-Neretva and Krapina-Zagorje County and 1 in Lika-Senj, Karlovac and Međimurje County.

Table 3

Number of rural households with accommodation service in the 2012

\begin{tabular}{|c|c|}
\hline County & $\begin{array}{c}\text { Number of rural households with } \\
\text { accommodation service }\end{array}$ \\
\hline Zagreb & 3 \\
\hline Lika-Senj & 1 \\
\hline Šibenik-Knin & 3 \\
\hline Istria & 5 \\
\hline Dubrovnik-Neretva & 2 \\
\hline Krapina-Zagorje & 2 \\
\hline Sisak-Moslavina & 9 \\
\hline Karlovac & 1 \\
\hline Koprivnica-Križevci & 4 \\
\hline Bjelovar-Bilogora & 3 \\
\hline Osijek-Baranja & 23 \\
\hline Vukovar-Srijem & 4 \\
\hline Međimurje & 1 \\
\hline Total Croatia & $\mathbf{6 1}$ \\
\hline
\end{tabular}

Source: Ministry of Tourism of the Republic of Croatia, January 2013 
Tourist rural family households, besides tourism offer, also attract guests by design/ appearance, i.e. attractiveness of the households or buildings where guests are offered different catering and tourist services. In the case of the attractiveness of tourist rural family households, a crucial importance has traditional architecture and the manner of construction. Most of those surveyed classified their facilities in a group of traditional (indigenous) or partly traditional buildings. There are few new facilities; only 17 in total, and 8 of them were built in the traditional style. There are more reconstructed or partly reconstructed buildings in the traditional style (34 households), and partly traditional facilities (also 34). In further development of tourist rural family households, attention should be given to traditional appearance of the family households and support reconstruction and restoration of old traditional estates i.e. villages and hamlets, and to make the existing ones as traditional as possible.

The research further shows the number of accommodation units in Croatian rural tourism, with the exceptions of the counties of Istria, Zadar and Osijek-Baranja, is still inappropriate, i.e. insufficient. Increased development of stationary, overnight tourism in rural areas of Croatia is the sole possibility for extending the stay of domestic and international guests in villages (Table 4).

Table 4

Number of registered beds, as per county, in 2007

\begin{tabular}{|c|c|}
\hline County & Number of beds \\
\hline Bjelovar-Bilogora & 16 \\
\hline Dubrovnik-Neretva & 23 \\
\hline Istria & 253 \\
\hline Koprivnica-Križevci & 22 \\
\hline Krapina-Zagorje & 20 \\
\hline Međimurje & 10 \\
\hline Osijek-Baranja & 192 \\
\hline Sisak-Moslavina & 27 \\
\hline Split-Dalmatia & 12 \\
\hline Šibenik-Knin & 16 \\
\hline Varaždin & 6 \\
\hline Vukovar-Srijem & 0 \\
\hline Zadar & 248 \\
\hline Zagreb & 41 \\
\hline Total & $\mathbf{8 8 6}$ \\
\hline
\end{tabular}

Source: Croatian Chamber of Economy, Tourism Department, Zagreb, 2007

The research results for the supply of accommodation units exhibit the existence of a larger number of households, which do not provide nutrition services, having accommodation as the exclusive offer - which occasionally includes breakfast. These are chiefly facilities with no agricultural production - these are, therefore, not registered as rural family households, but as citizens - renters, just like the classical rural bed \& breakfast, providing breakfast service. Such research results confirm the necessity to diversify the types of facilities that would provide catering, i.e. accommodation services in Croatian rural areas that were mostly tourist rural family 
households so far, and the necessity to enrich these with other tourist offers, in the form of advancing the fundamental tourist offer of these facilities in the rural area.

It is obvious that a large number of registered tourist rural family households dominate, with mostly half-day and single-day excursion tourism, with nutrition services in excursion facilities, wine facilities and theme tasting facilities (wine, olive oil, cheese, honey and other indigenous products of tourist rural family households).

As for working hours of tourist rural family households, these are not defined by law and this very fact leaves working hours to individual households. Most tourist rural family households opted for working during the whole week, prior telephone reservation provided (56 out of 88 surveyed). Without reservation, 18 households are open every day, while the rest has some other working hours. Seasonal tourist rural family households are few, and these are mostly found along the Croatian coast. The biggest problem as far as working hours of the households are concerned, in most cases, is the obligatory reservation, which is understandable for tourism is mostly an additional activity to hosts, who spend most of their time doing agriculture. Such working hours, on the other hand, limit the guests, because spontaneity and the spirit of adventure travelling or excursion are lost. It would, therefore, be desirable to find a solution acceptable to all, which would be obligatory for all tourist rural family households.

When discussing labor at tourist rural family households, survey conducted by the Croatian Chamber of Economy, Tourism Department, results have shown that, in most cases, the households employ mainly family members. The households surveyed, employ 382 persons in total, out of which 348 (91\%) are family members and 34 (9\%) additional labor. Out of the total number of households surveyed, 16 of them (19\%) employ additional labor. In average, 4 family members and 0,4 additional laborers are employed by one household.

As far as marketing is concerned, it has been determined there is no organized, joint marketing of tourist rural family households at the country level. Certain forms of marketing do exist at the level of individual counties (this mostly includes county catalogues or web pages in rare cases). Most households surveyed have own marketing materials, flyers or catalogues, postcards or web pages. Almost all surveyed tourist rural family households, 72 of them, state friends or acquaintances, i.e. wordof-mouth transfer of information and impressions as the most frequent form of marketing. Sixty tourist rural family households advertise through own flyers, more than a half via tourist boards, and slightly less than half cooperate with tourist agencies. It is one third of households that advertise through radio, TV, newspapers and fairs (presentation). A national catalogue of rural tourism in Croatia is required for future marketing and development of tourist rural family households, as well as increased advertising in home and international fairs.

Within marketing activities of tourist rural family households, a crucial role is played by sales of indigenous souvenirs. It is, unfortunate, slightly above one half of surveyed households that have souvenirs as part of their offer. It is, therefore, necessary to increase networking in this segment, and cooperation with traditional crafts and tourist boards. 
One half of tourist rural family households surveyed participated in some form of training or seminars organized in order to acquaint members of households with legal regulations, taxes, subsidies, rights and duties, and other specific know-how and skills required for managing and running a tourist rural family household. All those surveyed participated in some form of training, given high marks for the same, and emphasizing the need to continue their organization.

\subsubsection{Facilities and capacities of rural tourism in Croatia}

Accommodation facilities are basic and typical receptive factor of tourist destination, which means that from their size mostly depends the tourist traffic, and their types, forms and qualities directly affect the types and forms of tourism, and thus on it economic effects. In the function of rural tourist accommodation in Croatia are available tourist rural family households, hotels in mountains and other places in the Croatian inland, health-thermal resorts, campsites, and a large number of nutrition facilities.

According to the official statistical records, to rural tourists in Croatia are available accommodation capacities (rooms, apartments, campsites) in 12 predominantly rural Croatian counties (Krapina-Zagorje, Sisak-Moslavina, Karlovac, Varaždin, KoprivnicaKriževci, Bjelovar-Bilogora, Virovitica-Podravina, Požega-Slavonija, Slavonski BrodPosavina, Osijek-Baranja, Vukovar-Srijem and Medimurje) in the total number of 7970 (Table 5). The largest number of accommodation capacities is in the PrimorjeGorski Kotar County (1890), and the lowest in Požega-Slavonia County (188).

Table 5

Accommodation capacities in 12 predominantly rural Croatian counties, as of August 31, 2011

\begin{tabular}{|c|c|}
\hline County of & $\begin{array}{c}\text { Accommodation capacities, as of August 31, 2011 } \\
\text { Rooms, apartments and campsites }\end{array}$ \\
\hline Krapina-Zagorje & 966 \\
\hline Sisak-Moslavina & 472 \\
\hline Karlovac & 1890 \\
\hline Varaždin & 1100 \\
\hline Koprivnica-Križevci & 255 \\
\hline Bjelovar-Bilogora & 380 \\
\hline Primorje-Gorski Kotar* & 65,949 \\
\hline Lika-Senj* & 10,580 \\
\hline Virovitica-Podravina & 237 \\
\hline Požega-Slavonija & 188 \\
\hline Slavonski Brod-Posavina & 305 \\
\hline Osijek-Baranja & 1141 \\
\hline Vukovar-Srijem & 502 \\
\hline Međimurje & 534 \\
\hline
\end{tabular}

* mountain resorts

Source: Croatian Bureau of Statistics (2011). Statistical Yearbook of the Republic of Croatia. Zagreb: Croatian Bureau of Statistics, 427. 
Regarding tourist arrivals of domestic and foreign tourists in 12 predominantly rural counties in Croatia, last statistical data show that it has been achieved total of 494,464 tourist arrivals and a total of 1,069,766 overnight stays of domestic and foreign tourists (Table 6). The highest overall tourist arrivals of domestic and foreign tourists were recorded in Karlovac County (163,754), and lowest in Požega-Slavonija (9014). Most overnight stays of domestic and foreign tourists were again achieved in Karlovac County $(282,083)$, and lowest in Požega-Slavonija County $(18,786)$.

Table 6

Tourist arrivals and tourist nights in 12 predominantly rural Croatian counties, as of August 31, 2011

\begin{tabular}{|c|c|c|c|c|c|c|}
\hline \multirow[b]{2}{*}{ County of } & \multicolumn{3}{|c|}{ Tourist arrivals } & \multicolumn{3}{|c|}{ Tourist nights } \\
\hline & Total & $\begin{array}{c}\text { Domestic } \\
\text { tourists }\end{array}$ & $\begin{array}{l}\text { Foreign } \\
\text { tourists }\end{array}$ & Total & $\begin{array}{l}\text { Domestic } \\
\text { tourists }\end{array}$ & $\begin{array}{l}\text { Foreign } \\
\text { tourists }\end{array}$ \\
\hline Krapina-Zagorje & 54,781 & 41,929 & 12,852 & 145,411 & 118,108 & 27,303 \\
\hline Sisak-Moslavina & 26,991 & 14,839 & 12,152 & 87,385 & 61,934 & 25,451 \\
\hline Karlovac & 163,754 & 25,091 & 138,663 & 282,083 & 66,439 & 215,644 \\
\hline Varaždin & 38,518 & 20,666 & 17,852 & 116,601 & 81,321 & 35,280 \\
\hline $\begin{array}{c}\text { Koprivnica- } \\
\text { Križevci }\end{array}$ & 12,093 & 7,718 & 4,375 & 20,075 & 13,035 & 7,040 \\
\hline Bjelovar-Bilogora & 11,590 & 8,080 & 3,510 & 23,981 & 16,936 & 7,045 \\
\hline $\begin{array}{c}\text { Primorje-Gorski } \\
\text { Kotar* }\end{array}$ & $2,151,118$ & 307,668 & $1,843,450$ & $10,938,291$ & $1,193,855$ & $9,744,436$ \\
\hline Lika-Senj* & 403,960 & 34,615 & 369,345 & $1,618,941$ & 123,857 & $1,495,084$ \\
\hline $\begin{array}{l}\text { Virovitica- } \\
\text { Podravina }\end{array}$ & 12,991 & 10,545 & 2,446 & 34,323 & 28,712 & 5,611 \\
\hline Požega-Slavonija & 9,014 & 6,773 & 2,241 & 18,786 & 14,427 & 4,359 \\
\hline $\begin{array}{c}\text { Slavonski Brod- } \\
\text { Posavina }\end{array}$ & 18,099 & 8,984 & 9,115 & 31,951 & 17,039 & 14,912 \\
\hline Osijek-Baranja & 71,749 & 52,465 & 19,284 & 159,261 & 118,283 & 40,978 \\
\hline Vukovar-Srijem & 36,582 & 27,553 & 9,029 & 68,383 & 50,983 & 17,400 \\
\hline Međimurje & 38,302 & 27,422 & 10,880 & 81,526 & 60,374 & 21,152 \\
\hline
\end{tabular}

* mountain resorts

Source: Croatian Bureau of Statistics (2011). Statistical Yearbook of the Republic of Croatia. Zagreb: Croatian Bureau of Statistics, 427. 
Regarding tourist arrivals and overnight stays by type of catering facilities in rural areas in Croatia, the problem is the simultaneous existence of the official classification facilities of rural households engaged in rural tourism in Croatia and the unofficial market typology of households in rural tourism, which provide catering services in rural areas (e.g. agritourism, rural economy, farm, rural house, rural family-run hotel, guest house, rooms and apartments of traditional and/or the new architecture, etc.). Considering that there are no segmented data on tourist arrivals and overnight stays by type of catering facilities in rural areas in Croatia, the available data provide only overall picture. According to the official classification of types of catering facilities that is used in the annual statistical yearbooks, rural households were listed in the category of Private Accommodation Facilities, in the group of Households, which also includes Rooms, Apartments and Holiday Houses, so it is not possible to give an exact number of arrivals and overnight stays just for rural households. These data indicate the necessity of change and extend the types of catering facilities for that will be kept record of tourist traffic in order to obtain more precise picture of this segment of tourism research.

\subsubsection{Grants and incentive programs for the development of rural tourism in Croatia}

Development of rural tourism and entrepreneurship in rural tourism and rural areas in Croatia is financed by subsidies issued on a national level mainly by the Ministry of Tourism and in a smaller scale by the Ministry of Agriculture, and locally by the county and self-governing units, or by periodical international subsidies intended for rural tourism and grant projects.

Since 2005, the Ministry of Tourism of the Republic of Croatia for the development of rural tourism destinations with the preservation of identity of Croatian rural areas, granted supports and subsidies through two programs: De minimis aid grant programs without recurrence and Credit programs with subsidized interest rates.

De minimis aid grant programs without recurrence are:

- Program for encouraging protection, reconstruction and inclusion of cultural and natural heritage into tourist offer in touristic underdeveloped areas, „Heritage in Tourism",

- Program for encouraging development of theme tourist routes, "Thematic Routes", and

- Program for encouraging and improving production and sales of souvenirs, "Original Souvenir".

Credit programs with subsidized interest rates are:

- "Support for Success", and

- "Under the Ancient Roofs".

The last available official data for those two programs are from the year 2009. After that year, no any data are available, and they cannot be obtained for publication 
and commenting even through the official channels. After the year 2009, all these programs are still active, and state funds are allocated for them through public tenders and are issued once a year on the web pages of the Ministry of Tourism of the Republic of Croatia.

Program "Heritage in Tourism" have been subsidized from 2005 to 2009 and cofinanced 595 projects with the amount of 27,061,593,00 HRK/3,579,575,79 Euro. The programs "Thematic Routes" and "Original Souvenir" have been subsidized since 2007 and until 2009 co-financed 182 projects with 10,435,000,00 HRK/1,380,291,00 Euro, and 278 projects in total amounting to 5,365,000,00 HRK/709,656,08 Euro respectively (Table 7).

Table 7

Funding the programs „Heritage in Tourism“, „Thematic Routes" and „Original Souvenir" by the Ministry of Tourism of the Republic of Croatia in total numbers/amounts per program from 2005 to 2009

\begin{tabular}{|c|c|c|c|}
\hline Year & Program name & $\begin{array}{c}\text { Total number of } \\
\text { programs }\end{array}$ & Total amount in HRK/Euro * \\
\hline 2005-2009 & Heritage in Tourism & 595 & $27,061,593,00 / 3,579,575,79$ \\
\hline 2007-2009 & Thematic Routes & 182 & $10,435,000,00 / 1,380,291,00$ \\
\hline 2007-2009 & Original Souvenir & 278 & $5,365,000,00 / 709,656,08$ \\
\hline Total & & $\mathbf{1 0 5 5}$ & $\mathbf{4 2 , 8 6 1 , 5 9 3 , 0 0 / 5 , 6 6 9 , 5 2 2 , 8 8}$ \\
\hline
\end{tabular}

*1 HRK is approximately 7,56 Euro

Source: Ministry of Tourism of the Republic of Croatia, January 2013

Table 8 shows funding "De minimis aid grants programs" per program name and number of programs per year from 2005 to 2009.

Table 8

Funding the programs „Heritage in Tourism“, „Thematic Routes“ and „Original Souvenir" by the Ministry of Tourism of the Republic of Croatia per year from 2005 to 2009

\begin{tabular}{|c|c|c|c|}
\hline Year & Program name & Number of programs & Amount in HRK/Euro* \\
\hline 2005 & Heritage in Tourism & 56 & $3,456,593,00 / 457,221,29$ \\
\hline 2006 & Heritage in Tourism & 61 & $3,500,000,00 / 462,962,96$ \\
\hline \multirow{3}{*}{2007} & Heritage in Tourism & 78 & $4,950,000,00 / 654,761,90$ \\
\cline { 2 - 4 } & Thematic Routes & 33 & $2,500,000,00 / 330,687,83$ \\
\cline { 2 - 4 } & Original Souvenir & 60 & $1,000,000,00 / 132,275,13$ \\
\hline \multirow{3}{*}{2008} & Heritage in Tourism & 219 & $8,000,000,00 / 1,058,201,05$ \\
\cline { 2 - 4 } & Thematic Routes & 86 & $4,500,000,00 / 595,238,09$ \\
\cline { 2 - 4 } & Original Souvenir & 138 & $2,500,000,00 / 330,687,83$ \\
\hline \multirow{3}{*}{2009} & Heritage in Tourism & 181 & $7,155,000,00 / 946,428,57$ \\
\cline { 2 - 4 } & Thematic Routes & 63 & $3,435,000,00 / 454,365,07$ \\
\cline { 2 - 4 } & Original Souvenir & 80 & $1,865,000,00 / 246,693,12$ \\
\hline \multirow{2}{*}{ Total } & & 1055 & $42,861,593,00 / 5,669,522,84$ \\
\hline
\end{tabular}

* 1 HRK is approximately 7,56 Euro

Source: Ministry of Tourism of the Republic of Croatia, January 2013 
Programs "Heritage in Tourism", "Theme Routes" and "Original Souvenir" have aim to build better recognition of Croatia in whole as a diversified tourist country, to create thematically integrated and organized tourist attractions throughout the year linking natural and cultural heritage of Croatia, to revive economic activities by increasing consumption, to increase the number of tourist services providers in underdeveloped tourist areas, to encourage sustainable development, and to protect and preserve the heritage using traditional techniques and materials. However, regardless of the current success in the implementation of those three programs, the public is still not appropriate informed with their ultimate positive effects. Therefore, a thorough analysis of their results and realized examples is necessary to precisely define and articulate criteria of future grants and subsidies.

The ministries of Tourism and Agriculture issue credit programs in cooperation with the Croatian Bank for Reconstruction and Development (HBOR), Croatian Agency for Small Entrepreneurship (HAMAG) and business banks. Two of the most successful programs with support by the Ministry of Tourism of the Republic of Croatia and the Croatian Bank for Reconstruction and Development (HBOR) are "Support for Success and "Under the Ancient Roofs".

In the program "Support for Success", the Ministry of Tourism subsidizes interest rate of $1 \%$ to $4 \%$, with a long repayment period up to 20 years and with a grace period up to 2 years. Maximum capacity of the facilities that are financed must be 10 to 40 rooms and 7 to 20 apartments and each facility must meet the minimum categorization requirements of three stars. From 2002, the beginning of this program, until 2009 were realized 474 credits in the amount of 1,930,727,877,17 HRK/255,387,285,33 Euro. On the continent, 145 credits have been realized, in the coastal region 245 , and on the islands 84 . The largest number of credits was used for construction and renovation of accommodation facilities, 207, and mostly financed are the hotels/ guest houses/apart hotels, 357, and minimum campsites, only 6 (Table 9).

In the program "Under the Ancient Roofs", which main goal is the preservation of traditional architecture, from 2002 to 2009 were restored 107 buildings of cultural heritage, and 17 of them in continental counties (Table 9).

Table 9

Program „Support for Success“ - results of implementation 2002-2009

\begin{tabular}{|c|c|c|c|c|c|c|c|c|}
\hline \multicolumn{2}{|c|}{ Approved credits } & \multicolumn{2}{|c|}{$\begin{array}{l}\text { Number of } \\
\text { credits by } \\
\text { type of user }\end{array}$} & \multicolumn{3}{|c|}{$\begin{array}{l}\text { Number of credits by } \\
\text { investment location }\end{array}$} & \multicolumn{2}{|c|}{$\begin{array}{l}\text { Number of credits by } \\
\text { investment purpose }\end{array}$} \\
\hline $\begin{array}{c}\text { Total } \\
\text { num- } \\
\text { ber }\end{array}$ & $\begin{array}{c}\text { Amount in HRK/ } \\
\text { Euro* }\end{array}$ & Craft & $\begin{array}{l}\text { Trading } \\
\text { com- } \\
\text { pany/ } \\
\text { coopera- } \\
\text { tive }\end{array}$ & Continent & $\begin{array}{l}\text { Coast- } \\
\text { al area }\end{array}$ & Islands & $\begin{array}{c}\text { Construction/ } \\
\text { renovation }\end{array}$ & $\begin{array}{l}\text { "Under } \\
\text { the } \\
\text { Ancient } \\
\text { Roofs" }\end{array}$ \\
\hline 474 & $\begin{array}{c}1,930,727,877,17 / \\
255,387,285,33\end{array}$ & 226 & 248 & 145 & 245 & 84 & 207 & 107 \\
\hline
\end{tabular}




\begin{tabular}{|c|c|c|c|c|c|c|}
\hline \multicolumn{2}{|c|}{ Credited accommodation facilities/buildings } & \multicolumn{3}{|c|}{$\begin{array}{c}\text { Accommodation units in credited } \\
\text { facilities/buildings }\end{array}$} \\
\hline $\begin{array}{c}\text { Hotels/ } \\
\text { guest } \\
\text { houses/ } \\
\text { apart hotels }\end{array}$ & $\begin{array}{c}\text { Apartments/ } \\
\text { rooms }\end{array}$ & $\begin{array}{c}\text { Holiday } \\
\text { houses }\end{array}$ & Campsites & Rooms & Apartments & Beds \\
\hline 357 & 79 & 34 & 6 & $\mathbf{5 , 8 4 5}$ & $\mathbf{1 , 0 9 7}$ & $\mathbf{1 5 , 1 5 0}$ \\
\hline
\end{tabular}

*1 HRK is approximately 7,56 Euro

Source: Ministry of Tourism of the Republic of Croatia, January 2013

Although both later credit programs are particularly clearly aimed at the final goal of a stronger economic development in rural areas in Croatia, both should be more transparent to the public because in that way their concrete final effects will become visible.

\section{Conclusion}

In Croatia rural tourism is a significant factor in activation and sustainable development of rural areas, which also helps in preserving local identities, traditions and customs, protects the environment, strengthens indigenous, traditional and ecological production, and develops rural areas based on sustainable development. The Croatian rural tourism hides enormous potential that is not given sufficient attention.

Considering its significance in creating new set of values in rural areas, rural tourism in Croatia is not given its true worth. Recently, national administration, local selfgovernments, individual institutions and entrepreneurs have shown some increased interest in development and promotion of the activity. Apart from various prerequisites, development, education, finances and promotion in particular, it is necessary to cooperate on all levels. It is necessary to stimulate cooperation between all institutions in charge (national administration, regional and local self-governments, tourist boards, regional developmental agencies, scientific and expert institutions, professional associations) in order to pursue the mutual goal of developing rural tourism and creating national program (strategy) for development of rural areas and Croatian tourism, and to stimulate cooperation of tourist rural family households and other entrepreneurs in rural tourism by strengthening the existing and forming new associations and cooperatives.

Guidelines for the further development of tourism in rural areas in Croatia would be following:

- achieve competitiveness of the whole Croatia in international markets,

- encourage self-employment and motivate young people to stay in rural areas,

- raise the quality level of accommodation, catering and tourism services,

- actively work on specific programs connecting two strategic sectors for development of rural areas: tourism and agriculture,

- encourage the production of organic food and indigenous products, and their sale through tourism infrastructure, 
- harmonize the supports and subsidies programs at all levels in order to achieve balanced regional development,

- $\quad$ systematically educate all participants and employees in rural tourism by adopting the theoretical and practical skills, and

- enrich overall tourism offer in rural areas because it directly stimulates the development of rural tourism destinations.

Encouraging the development of tourism is an excellent opportunity for the revitalization of rural areas, improve the economic development and promotion of Croatia as a unique tourist destination. In this way, the developed tourist regions and cities must provide greater financial and personnel support, working with the private sector, and in synergy with incentives and programs of relevant ministries and with local community develop destinations on rural areas.

The main objective of tourism in rural areas in Croatia must be improving the quality of life and preventing depopulation, and future development policy for all rural regions in Croatia should determine the concept of development with the condition of preserving its original characteristics, nature and cultural heritage.

\section{References}

1. Act on catering activity, Official Gazette 138 from 2006 and 80 from 2010. (in Croatian)

2. Act on providing services in tourism, Official Gazette 68 from 2007 and 88 from 2010. (in Croatian)

3. Baćac, R. (2010). Guidelines for the ideal status of rural tourism in Croatia: science fiction or needed reality?, in: Katica Dijana (ed.). Proceedings 1st Croatian congress on rural tourism with international participation "Development perspectives of rural tourism", Hvar, October 17 - 21, 2007. Zagreb: Hrvatski farmer, 23-26. (in Croatian)

4. Baćac, R. (2010a). Do we have agritourism we have imagined?, in: Katica Dijana (ed.). Proceedings 2nd Croatian congress on rural tourism with international participation "The concept of long-term development of rural tourism", Mali Lošinj, April 21 - 25, 2010. Zagreb: Hrvatski farmer, 29-32. (in Croatian)

5. Baćac, R. (2006). Agritourism - traditional values in tourism, in: Petrović Leš Tihana and Pletenac Tomislav (eds.). Proceedings Ethnology and cultural tourism. Zagreb: Department of Ethnology and Cultural Anthropology, Faculty of Humanities and Social Sciences, University of Zagreb, 36-42. (in Croatian)

6. Cetinski, V.; Katica, D. and Nušinović, M. (1998). The Program for development of small and medium entrepreneurship in tourism with an emphasis on sustainable development of tourism in rural areas. Zagreb: Ministry of Tourism of the Republic of Croatia. (in Croatian)

7. Cetinski, V.; Kušen, E. and Katica, D. (1995). Place and role of rural tourism in the Strategy for development of Croatian tourism, in: Katica Dijana (ed.). Tourism on rural economies - possibilities and limitations. Zagreb: Hrvatski farmer, 1-24. (in Croatian) 
8. Demonja, D. (2011). Croatian congresses on rural tourism: experiences and guidelines. Journal of Central European Agriculture, 12 (4): 660-672. (in Croatian with English summary)

9. Demonja, D. and Ružić, P. (2010). Rural tourism in Croatia with Croatian best practice examples and European experiences. Samobor: Meridijani. (in Croatian with English summary)

10. Katica, D. (ed.) (2010). Proceedings 1st Croatian congress on rural tourism with international participation "Development perspectives of rural tourism", Hvar, October 17- 21, 2007. Zagreb: Hrvatski farmer. (in Croatian)

11. Katica, D. (ed.) (2010a). Proceedings 2nd Croatian congress on rural tourism with international participation "The concept of long-term development of rural tourism", Mali Lošinj, April 21 - 25, 2010. Zagreb: Hrvatski farmer. (in Croatian)

12. Kušen, E. (2010). Terminology of rural tourism, in: Katica Dijana (ed.). Proceedings 1st Croatian congress on rural tourism with international participation "Development perspectives of rural tourism", Hvar, October 17- 21, 2007. Zagreb: Hrvatski farmer, 131-134. (in Croatian)

13. Kušen, E. (1997). Strategic framework for development of rural tourism as part of the concept of overall development of rural areas and village renewal, in: Proceedings "Rural tourism - one of the factors in the reconstruction of villages and integrated development of rural areas". Zagreb: Hrvatski farmer, 48-51. (in Croatian)

14. Kušen, E. (1995). Continental nautical tourism, in: Proceedings "The development of rural tourism in continental part of Croatia". Zagreb: Hrvatski farmer, 142-144. (in Croatian)

15. Kušen, E. (1995a). Residential tourism, in: Proceedings "The development of rural tourism in continental part of Croatia". Zagreb: Hrvatski farmer, 147-150. (in Croatian)

16. Kušen, E. (1995b). Tourism on rural farms. Turizam, 43 (7-8): 127-133. (in Croatian)

17. Kušen, E. (1992). Rural tourism and architecture of the village and rural economies, in: "Croatian Farmer - programs for development of rural family bousebolds". Zagreb: Globus, 365-382. (in Croatian)

18. Mišćin, L. and Mađer, B. (2008). Current state of tourism in Croatian rural areas 2008. Zagreb: Croatian Chamber of Economy, Tourism Department. Accessed on March 3, 2013. (http://hgk.biznet.hr/hgk/fileovi/13081.ppt). (in Croatian)

19. Regulation on keeping the list of tourists and the form and content of the registration form to the tourist board, Official Gazette 113 from 2009. (in Croatian)

20. Regulation on the classification and categorization of facilities that provide services in the rural household, Official Gazette 88 from 2007, 58 from 2008 and 45 from 2009. (in Croatian)

21. Regulation on the form, content and manner of keeping the guests book and the list of guests, Official Gazette 5 from 2008. (in Croatian)

22. Regulation on registers of catering facilities and on registers of providing catering services in the household and rural household, Official Gazette 5 from 2008. (in Croatian)

23. Regulation on the provision of catering services in rural household, Official Gazette 5 from 2008, 44 from 2011 and 118 from 2011. (in Croatian) 
24. Ministry of Agriculture, Fisheries and Rural Development of the Republic of Croatia (2008). Rural Development Strategy of the Republic of Croatia for the period 2008-2013. Zagreb: Ministry of Agriculture, Fisheries and Rural Development of the Republic of Croatia. (in Croatian)

25. Ružić, P. (2011). Rural Tourism in Istria: Preconditions and factors of development, status and perspectives. Pula: Institute for agriculture and tourism Poreč, Office for tourism. (in Croatian)

26. Ružić, P. (2009). Rural Tourism. Pula: Institute for agriculture and tourism Poreč. (in Croatian)

27. Croatian Bureau of Statistics (2011). Statistical Yearbook of the Republic of Croatia. Zagreb: Croatian Bureau of Statistics. (in Croatian)

28. Ministry of Tourism of the Republic of Croatia (2003). Strategy for development of Croatian tourism until the year 2010. Zagreb: Ministry of Tourism of the Republic of Croatia. Accessed on March 3, 2013. (http://www.mint.hr/UserDocsImages/Strategija\%20hrvatskog\%20turizma\%20-\%20finalna\%20verzija.pdf). (in Croatian) 
Pregledni rad

Damir Demonja

Institut za razvoj i međunarodne odnose, Zagreb, Hrvatska

e-mail:ddemonja@irmo.hr

\section{Pregled i analiza stanja ruralnog turizma u Hrvatskoj}

\section{Sažetak}

U ruralnoj Hrvatskoj koja čini 91,6\% ukupne površine, 44,4\% stanovništva je direktno ili indirektno vezano za poljoprivredu. Imajući na umu prirodnu i kulturnu raznolikost hrvatskih regija, bogatu ponudu turističkih atrakcija, dobro sačuvanu prirodu i 352 registrirana seoska domaćinstva, Hrvatska ima sve preduvjete za razvoj seoskog turizma i sve oblike turizma vezanog za ruralna područja. To je važno jer je na tržištu izrazito prisutna potražnja za ruralnim turizmom u svim njegovim brojnim oblicima. Seoska su područja, međutim, još uvijek nedovoljno iskorištena u turističkom smislu. Ruralni turizam u Hrvatskoj može postati jedna od glavnih determinanti razvoja u dosada marginaliziranim područjima. Razvoj turističke ponude, privlačan ulagačima i koji koristi jedinstveni lokalni potencijal, ima značajan utjecaj na rast bruto domaćeg proizvoda i zaposlenost. Rad se bavi predstavljanjem stanja i komentarom ruralnog turizma u Hrvatskoj. Baziran je na rezultatima prethodnih istraživanja ali i novijim podacima, te analizira situaciju u seoskome turizmu Hrvatske te općenito, analizira turističke objekte, kapacitete, programe potpore i poticaja. Napokon, sugeriraju se smjernice za održivi razvoj seoskog turizma u Hrvatskoj.

Ključne riječi: Hrvatska, ruralni turizam, pregled, analiza, stanje, smjernice, održivi razvoj. 